\title{
Peculiarities of the defining materiality of breach of procedural norms in relation to specific taxes
}

\author{
Maxim Igorevich Zimulkin* \\ Ural State Law University, Yekaterinburg, Russia
}

\begin{abstract}
The article in question deals with the problems of respect for the rights of taxpayers when applying the procedural provisions of Russian legislation with regards to specific taxes. The author stresses the need to ensure procedural guarantees of taxpayers not only in terms of the tax control implementation, but also in the tax authority's and the taxpayer's interaction within the framework of the calculation and collection of taxes. The article illustrates the consolidation of procedural provisions within the foreign jurisdictions' legislation, analyzes the procedural tax norms of the Russian tax legislation, as well as examines the problems arising from the current tax disputes. The author pays special attention to contentious situations in matters of obtaining a VAT deduction by taxpayers. Based upon the study results, the author comes to the conclusion that material breach of the Russian legislation's procedural provisions on taxes and fees are considered as illegal actions (inaction) of tax authorities, which are expressed in derogating taxpayers' procedural rights and, as a result, negatively affecting the balance of private and public interests.
\end{abstract}

\section{Introduction}

The modern doctrine assumes that the fundamental procedural rights of taxpayers must be guaranteed. Including procedural rights of taxpayers should be guaranteed within the framework of special tax procedures inherent in specific taxes $[1,7,8]$.

It should be assumed that in the implementation of tax audits [2] and the implementation of tax accounting for transport tax and other actions of tax authorities, tax authorities' activities shall be based upon the principle of legal certainty and legitimate expectations should be one of the grounds for the activities.

In addition, the taxpayers should also be guaranteed the right to information and to own position submission not only during the results of a tax audit registration [3], but also in the framework of other tax procedures, such as, for example, the transition to special tax regimes.

H. Skalicka and P. Skalicky address the problems of compliance with procedural rules that determine the procedure for interaction between a taxpayer and a tax authority in the calculation and payment of specific taxes in the Czech Republic. H. Skalicka and P. Skalicky, as an example, present the problem of breach by the tax authority of the timing of the procedure for removing doubts when checking the correctness of VAT calculation (the so-called Procedure for removal of doubt) [4].

The legal doctrine of the Kingdom of Norway, in turn, indicates the unconditional right of the taxpayer to receive information from the tax authority, as well as to submit the necessary objections regarding information that is the basis for changing the amount of income tax (for example, responses from the competent authorities of foreign states) [5].

In the Kingdom of Belgium, a material breach of procedural norms is the adoption by the tax authority of a decision on additional accrual of income tax amounts before the expiration of the one month presented to the taxpayer for the preparation of explanations [6].

The legislation of the Russian Federation on taxes and fees contains many provisions governing the procedure for carrying out tax procedures inherent in specific taxes, which should also be studied to determine the notion of the materiality of breach of procedural norms.

Undoubtedly, most of the procedural tax and legal norms are contained in the first part of the Tax Code of the Russian Federation [9]. The first part of the Tax Code of the Russian Federation includes provisions regulating, in particular, the implementation of tax control measures and the consideration of tax audit materials.

At the same time, certain procedural norms are contained in the chapters of the Tax Code of the Russian Federation, which regulate the specifics of specific taxes, which is due to the presence of specific procedures inherent exclusively to certain taxes and fees.

Given the presence of a significant number of procedural provisions in other chapters of the second part of the Tax Code of the Russian Federation, there is a justified need to analyze them through a systematic approach. 
Following the logic of the legislator, according to which provisions on individual taxes are consistently reflected in the second part of the Tax Code of the Russian Federation, it is considered necessary to highlight the following tax procedures and, accordingly, procedural rules.

Chapter 21 of the Tax Code of the Russian Federation, which establishes the main elements of VAT taxation, the procedure for calculating and paying VAT, contains a significant number of procedural norms [4].

Certain provisions of Articles 145 and 145.1 of the Tax Code of the Russian Federation contain legal norms establishing the procedure for exemption from the duties of payers (as well as their individual types) of valueadded tax [4].

The provisions of Article 169.1 of the Tax Code of the Russian Federation determine the procedure and conditions for compensation of the amount to foreign citizens when exporting goods outside the Eurasian Economic Union [4].

Procedural rules governing the procedure for taxpayers to receive a deduction for VAT and the restoration of amounts presented for a deduction are contained in Articles 171 - 172 of the Tax Code of the Russian Federation [4].

In addition, legal norms governing the specifics of certain procedures related to the application of VAT can be found in the provisions of Articles 174, 174.1, 174.2, 176, 176.1 of the Tax Code of the Russian Federation, which, in essence, also cannot be called an exhaustive list [4].

Of course, the regulation of social relations associated with the payment of excise taxes is also not possible without procedural rules.

In this case, procedural rules establish the rules for calculating, paying, and reporting excise taxes and the procedure for obtaining certificates of registration of a person performing transactions with excisable goods.

Chapter 22 of the Tax Code of the Russian Federation contains legislative provisions regulating the specifics of calculating and paying excise taxes. Chapter 22 of the Tax Code of the Russian Federation, in particular, contains the following articles, which include legal norms of a procedural nature: 179 - 180, 184, 186.1, 201, 203, 203.1, 204, 205, 205.1 of the Tax Code of the Russian Federation [4].

Chapter 23 of the Tax Code of the Russian Federation regulates the specifics of establishing, calculating, and paying personal income tax. In the gleam 23 of the Tax Code of the Russian Federation, procedural provisions that determine the procedure for filling out and filing a tax declaration (Article 229 of the Tax Code of the Russian Federation), the procedure for collecting and refunding tax (Articles 231, 231 of the Tax Code of the Russian Federation) are of particular importance [4].

It should be noted that the following chapters contain norms establishing specific taxes, fees, insurance premiums, as well as regulating the taxation procedure when applying special tax regimes. The chapters of the Tax Code of the Russian Federation also contain procedural provisions, the significance of which for tax legal relations should not be underestimated. Each of the chapters of part two of the Tax Code of the Russian Federation contains special procedural norms aimed at regulating certain features of calculation, payment, reporting, return, control, and other procedures for interaction between the taxpayer and the tax authorities.

At the same time, it is considered necessary to define the concept of materiality of breach of procedural rules concerning specific taxes. This study is made possible by analyzing real-life examples presented by tax disputes. Of most significant interest, in this case, are the problems arising in law enforcement practice of exemption from the duties of a payer of value-added tax if, following the results of a tax audit, the activities of these individuals were qualified by the tax authorities as entrepreneurial.

\section{Materials and methods}

The methodological basis of the research is represented by philosophical, general scientific, and specific scientific methods, which the author used for achieving the results of scientific research.

The dialectical-materialistic method of cognizing objective reality is the primary method based on which all scientific research is carried out. The study of legislation and judicial practice was carried out through analysis.

When studying judicial practice, a ranking method is used, allowing working only with the main conclusions contained in judicial acts and having value for research. Synthesis, generalization, and abstraction make it possible to establish a general approach to the problem under consideration.

The work is largely based on the inductive method of theoretical research. Applying this method is based on theories, regulations, and conclusions of judicial practice in deriving the criteria common to all the materiality criteria for breaches of procedural rules concerning specific taxes.

Analysis of the collected sources and interpretation of legal texts involves the use of a formal legal method.

The study of examples of legal regulation of the considered sphere of public relations involves using the comparative-legal method.

\section{Results}

Under paragraph 1 of paragraph 1 of Article 145 of the Tax Code of the Russian Federation, payers of the unified agricultural tax have the right to exemption from tax obligations if their earnings in the three preceding consecutive months amounted to more than 2,000,000 rubles [4].

In order to do this, following the provisions of paragraph 3 of Article 145 of the Tax Code of the Russian Federation, they must, no later than the 20th day of the month from which the right to exemption arises, submit to the tax authority a notice of exemption from tax obligations [4]. 
Thus, the tax legislation provides a kind of tax benefit for organizations and individual entrepreneurs with a relatively small amount of proceeds from the sale of goods (works, services).

At the same time, situations arise in law enforcement practice related to the breaches by tax authorities of the rights of taxpayers-individuals, whose activities, based on the results of a tax audit, were qualified by the tax authorities as entrepreneurial. For example, when an entrepreneur submits a designated notification and receives a tax benefit.

A complete study of this issue is considered impossible without an analysis of the law enforcement approach set out in the acts of the Supreme Court of the Russian Federation [14].

Within the framework of this case, following the results of a tax audit, the activity of an individual on leasing non-residential premises was qualified as an entrepreneurial activity carried out by an individual who is not registered as an individual entrepreneur in the manner prescribed law.

Considering the above and following the provisions of paragraph 2 of Article 11, paragraph 1 of Article 143, and subparagraph 1 of paragraph 1 of Article 146 of the Tax Code of the Russian Federation, individuals were additionally charged the amount of value-added tax [14].

Resolving a tax dispute related to the requalification of an individual's activities and the accompanying additional tax assessment and bringing to tax liability, the Judicial Collegium for Administrative Cases of the Supreme Court of the Russian Federation made significant conclusions regarding the procedural features of ensuring the taxpayer's right to exemption from duties on value-added tax.

In particular, the court noted that within the meaning of the provisions of paragraph 1 of Article 145 of the Tax Code of the Russian Federation, the institution of exemption from the fulfillment of duties of a taxpayer is due to the need to comply with the income of a commodity producer to the limit established in the law and is aimed at reducing the tax burden of certain categories of taxpayers [14].

At the same time, the court indicated that failure to submit to the tax authority a notice of exemption from the duties of a value-added taxpayer could not deprive an individual of the relevant benefits. The previous follows from the conclusion of the court that the deprivation of the right to the exemption would be a disproportionate consequence of a formal breach committed by the taxpayer [14].

It should be noted that substantiating its position, the Supreme Court of the Russian Federation pointed to the clarifications contained in paragraph 2 of paragraph 2 of the Decision of the Plenum of the Supreme Commercial Court of the Russian Federation of 05/30/2014 No. 33 On issues arising from commercial courts when considering cases related to tax collection value-added, that the taxpayer only informs the authorized body of its intention to exercise its right to exemption from tax. The consequences of violating the time limit for sending a notification are not established by tax legislation [11].
In this case, an integral and consistent position of the Supreme Court of the Russian Federation is traced in implementing and applying procedural norms governing the issues of exemption of value-added taxpayers from performing their duties.

Pointing to the breaches committed by the tax authority, the court also indicates the peculiarities of the implementation of the provisions on exemption of the taxpayer from paying tax if there was a requalification following the results of a tax audit.

The position of the court is that the inspected person does not lose the right to be exempted from the fulfillment of the tax obligation if, within the framework of tax control measures and after the retraining of the taxpayer's activities, it has not declared its intention to exercise its right [14].

Moreover, the Supreme Court of the Russian Federation noted the presence of a special logic in the investigated procedural behavior of the taxpayer. The reason is that the notification by the audited people of the tax authority within the framework of tax control measures of the intention to exercise the right to exemption from tax obligation could weaken their position (the behavior of the audited person could be recognized as inconsistent) and deprive the right to defense [14].

Thus, the Supreme Court of the Russian Federation, resolving a specific dispute, actually clarified the procedural features of the implementation and application of the provisions of Article 145 of the Tax Code of the Russian Federation in the event of retraining the activities of a taxpayer who is an individual.

The legal position set out in the judicial act is undoubtedly aimed at ensuring the exercise of taxpayers' rights in cases where the actual circumstances of a particular dispute do not imply the taxpayer's ability to follow the strict model of behavior prescribed by law.

Analyzing the indicated position, the Supreme Court of the Russian Federation should indicate the origins of its formation.

The fundamental conclusions that can be determined as the basis for forming the analyzed law enforcement approach can be seen in the judicial acts of the Supreme Commercial Court of the Russian Federation [13].

It was within the framework of the tax dispute, following the consideration of which the designated judicial act was issued, that the problem of the lack of procedural rules governing the exemption from the duty of a value-added taxpayer was identified, in the event that the rights and obligations of a taxpayer were identified following the results of a tax audit.

Resolving the specified legal problem, the court made the following conclusion. The legislation of the Russian Federation on taxes and fees does not regulate the procedure for a taxpayer to exercise right to be exempted from a tax obligation in the event that the auditee learned about the need to pay VAT solely as a result of tax control measures. This situation does not mean the impossibility of exercising this right by the taxpayer [13].

However, considering the above precedent, it should be noted that in this case, the taxpayer declared that he 
was exempt from the duties of a value-added taxpayer at the stage of tax control measures.

The decision of the Presidium of the Supreme Commercial Court of the Russian Federation [13] by a judicial act containing the main conclusions for the formation of the considered legal position notes the consolidation of the investigated law enforcement approach in judicial practice and its substantive development. In particular, this decision can be noted based on the conclusions contained in judicial acts of the Supreme Court of the Russian Federation [14].

The stability of the law enforcement approach is expressed in the multiplicity of judicial acts that broadcast the investigated legal position [15-19]. Also, the stability of the law enforcement approach is in consolidating the main conclusions in the reviews of the practice of the Supreme Court of the Russian Federation, including in paragraph 31 of the Review of judicial practice of the Supreme Court of the Russian Federation No. 2 (2018) (approved by the Presidium of the Supreme Court of the Russian Federation on 07/04/2018) [12].

The circumstances of the development of the law enforcement approach are because if the judicial act of the Presidium of the Supreme Commercial Court of the Russian Federation [13] indicated the right of the taxpayer to receive benefits in the form of exemption from the obligation to pay value-added tax. The examined definition of the Supreme Court of the Russian Federation [14] contains a tendency to exempt the taxpayer from the need to declare a benefit within the framework of tax control measures and imposing the obligation on the tax authority, in case of requalification of the taxpayer's actions, to consider the provisions of paragraph 1 of Article 145 of the Tax Code of the Russian Federation [10].

The previous, among other things, is confirmed by the conclusions contained in the judicial acts of the lower courts [16, 20].

Overruling the decision of the court of the first instance, the appellate court points out that "the tax authority, having established the unjustified application of the simplified tax system, should have determined that the applicant had this right on the basis of the documents submitted and studied during the audit. Therefore, the fact that the entrepreneur during the on-site tax audit, a statement was not made on the application of article paragraph 1 of article 145 of the Tax Code of the Russian Federation, should not deprive him of the corresponding right. The fact that the tax authority notified the entrepreneur about right to exemption from VAT, and the entrepreneur did not declare its application, also cannot be considered, since the entrepreneurs considered themselves a payer under the simplified tax system, so such a statement for him would actually mean consent with the position of the tax authority" [20].

Therefore, we may observe a developing positive trend in law enforcement practice in terms of implementing procedural norms governing the procedure for obtaining benefits for value-added tax.

\section{Conclusions}

The existing law enforcement approach expands the guarantees of taxpayers compared to the content of the provisions of tax legislation. However, introducing the necessary changes to Article 145 of the Tax Code of the Russian Federation will eliminate the legal gap, bringing the procedural structure set out by the legislator to its logical ideal.

In the light of the above, illegal actions (inaction) of officials of tax authorities are recognized as material breaches of procedural norms of the legislation of the Russian Federation on taxes and fees. Illegal actions (inaction) of tax officials are expressed in diminishing the procedural rights of taxpayers and, as a result, negatively affect the balance of private and public interests.

Acknowledgments: The reported study was funded by RFBR, project number 20-311-90046.

\section{References}

1. P. Pistone, General Report, in Tax Procedures (P. Pistone, ed.) EATLP Annual Congress (Madrid 2019) pp. 3-114.

2. A. Eijsden, B. Killmann, F. Meussen, J. Dam, D. Smit, General Part, in Procedural Rules in Tax Law in the Context of European Union and Domestic Law (M. Lang, P. Pistone, J. Schuch, C. Staringer (eds.) (Kluwer Law International, 2010) pp. 3-48.

3. N. Cicin-Sain, Joint and Simultaneous Audits, in Tax Procedures (P. Pistone, ed.) EATLP Annual Congress (Madrid 2019) pp. 151-176.

4. H. Skalicka, P. Skalicky, Czech Republic, in Tax Procedures (P. Pistone, ed.) EATLP Annual Congress (Madrid 2019) pp. 265-282.

$5 . \quad$ G. Thue, Norway, in Tax Procedures (P. Pistone, ed.) EATLP Annual Congress (Madrid 2019) pp. 597-619.

6. E. Richelle, Belgium, in Procedural Rules in Tax Law in the Context of European Union and Domestic Law (M. Lang, P. Pistone, J. Schuch, C. Staringer (eds.) (Kluwer Law International, 2010) pp. 117-143.

7. D.V. Vinnitskiy, Russian Tax Law: Problems of Theory and Practice (Legal Center Press Publishing house, St. Petersburg, 2003) p. 395.

8. D.V. Vinnitskiy, Tax Procedural Law and Tax Process: Problems of Formation, Legislation, 2, 2331 (2003)

9. Tax Code of the Russian Federation (Part One) dated July 31, 1998 No. 146-FZ (with last amendments and additions as of July 20, 2020). Retrieved from: SPS ConsultantPlus.

10. Tax Code of the Russian Federation (part two) dated 05.08.2000 No. 117-FZ (with last amendments and 
additions as of 15.10.2020). Retrieved from: SPS ConsultantPlus.

11. Decision of the Plenum of the Supreme Commercial Court of the Russian Federation of 05/30/2014 No. 33 On issues arising from commercial courts when considering cases related to the collection of value added tax. Retrieved from: SPS ConsultantPlus.

12. Review of judicial practice of the Supreme Court of the Russian Federation No. 2 (2018) (approved by the Presidium of the Supreme Court of the Russian Federation on 04.07.2018). Retrieved from: SPS ConsultantPlus.

13. Decision of the Presidium of the Supreme Commercial Court of the Russian Federation dated 09.24.2013 No. 3365/13 on case No. A52-1669 (2012). Retrieved from: SPS ConsultantPlus.

14. The cassation ruling of the Judicial Collegium for Administrative Cases of the Supreme Court of the Russian Federation dated 04/10/2019 No. 51-KA191. Retrieved from: SPS ConsultantPlus.

15. Decision of the Judicial Collegium for Economic Disputes of the Supreme Court of the Russian Federation dated January 31, 2018 No. 306-KG17-
15420 in case No. A57-25507 (2016). Retrieved from: SPS ConsultantPlus.

16. Decision of the CA of the East Siberian District of 05.27.2020 No. F02-2171 / 2020, F02-2592 / 2020 on case No. A10-2828 (2019). Retrieved from: SPS ConsultantPlus.

17. Decision of the Commercial Court of the Central District of 06.02.2019 No. F10-6206 / 2018 on case No. A35-2974 (2017). Retrieved from: SPS ConsultantPlus.

18. Decision of the Commercial Court of the North-West District of July 17, 2017 No. F07-6548 / 2017 on case No. A42-4001 (2016). Retrieved from: SPS ConsultantPlus.

19. Decision of the Commercial Court of the Ural District of 13.09.2016 No. F09-2433 / 16 on case No. A71-4100 (2015). Retrieved from: SPS ConsultantPlus.

20. Decision of the Fourth Commercial Court of Appeal dated February 19, 2020 No. 04AP-5434/2019 on case No. A10-2828 (2019). Retrieved from: SPS ConsultantPlus. 